\title{
Wetting-induced collapse behaviour of a natural and vegetated coarse pyroclastic soil
}

\author{
Vittoria Capobianco ${ }^{1,2}$, Leonardo Cascini ${ }^{2}$, Sabatino Cuomo ${ }^{2, *}$ and Vito Foresta ${ }^{2}$ \\ ${ }^{1}$ Natural Hazards division, Norwegian Geotechnical Institute (NGI), Norway \\ ${ }^{2}$ Department of Civil Engineering, University of Salerno (UniSa), Italy
}

\begin{abstract}
Unsaturated pyroclastic soils originated by Vesuvius volcano show a collapsible behaviour upon wetting with a significant reduction in volume and rearrangement of solid skeleton. The paper investigates the role played by vegetation on wetting-induced collapse behaviour (namely, collapsibility) of reconstituted unsaturated soil specimens through two series of wetting tests in a standard oedometer. The first series of tests was performed on bare soil specimens, as to resemble the site conditions. The second group of tests was conducted on the same soil previously vegetated for 20 weeks with perennial graminae species, which are frequently used as a nature-based solution for contrasting surface erosion along slopes in different geo-environmental contexts. First, an initial small vertical net stress was applied on partially saturated specimens having similar initial saturation degree, then collapse was induced by flooding the specimens with distilled water and final vertical displacements were measured. As main outcome, soil porosity is highly reduced by the growth of grass roots. Consequently, the potential wetting collapse in the rooted soils is inhibited by low values of porosity. For similar initial soil porosity, in both bare and vegetated specimens (after root growth), a further reduction of the volumetric collapse magnitude is observed.
\end{abstract}

\section{Introduction}

Air-fall pyroclastic deposits originated by eruption activities of the Vesuvius district (South Italy) are usually in loose partially saturated conditions [1] by covering the shallowest layers of the hillslopes around the volcanic area [2].

During rainfall, water infiltrates the ground and may induce volumetric collapse in loose unsaturated soils. The magnitude of collapse depends on many factors such as the initial saturation degree [3], the soil porosity or the net stress. In some cases, static liquefaction may even occur when water cannot freely move and the pore water pressures increase up to the annulment of mean effective stresses [4]. The presence of roots in the soil can reduce the deformability of loose soils in unsaturated conditions when subjected to external loading or to wetting during rainfall infiltration.

In the scientific literature, the presence of vegetation has been already considered beneficial for stabilizing shallow covers through the capability of roots to bind soil and to increase the shear strength of root-soil composite [5]. Moreover, a dense root network can reduce the threat of slope failure through the reduction of soil infiltrated water during rainy periods $[6,7]$ and the increment of soil suction due to evapotranspiration. However, the effect of roots on the deformability of collapsible soils in unsaturated conditions needs to be studied, since limited literature contributions showed that roots could change the soil structure through the occupancy of roots in soil pore space $[8,9]$ and the production of root exudates [10]. Some authors in the past investigated the effects of external loading or initial suction on the collapsibility of bare pyroclastic soils of Campania region, through standard oedometer tests [11, $12]$ and suction controlled oedometer tests [13, 14].

This paper extends the previous investigations to the effect of the roots on collapsible behaviour of pyroclastic soils due to wetting. Particularly, oedometer tests have been conducted either on vegetated specimens or bare specimens as control.

\section{Material and Methods}

\subsection{Soil and vegetation tested}

The material tested in this study is a non-plastic ashy soil [1] with the peculiarity of showing a metastable structure in undisturbed condition due to its air-fall deposition process. Recent X-ray investigations outlined the microscale behaviour of such soil under wetting. Particularly, the time-spatial evolution of clusters of voids and water contents were associated to an overall reduction of soil porosity [15]. Micro-mechanical modelling of such mechanical response has been also recently proposed [16]. The index properties of the investigated soil are summarized in Table 1 .

\footnotetext{
Corresponding author: scuomo@unisa.it
} 
Table 1. Index properties of pyroclastic soil investigated.

\begin{tabular}{|c|c|}
\hline Index Properties & Value \\
\hline \multicolumn{2}{|l|}{ Particle-size distribution } \\
\hline Gravel content $(>2 \mathrm{~mm}): \%$ & 8.09 \\
\hline Sand content: $\%$ & 60.20 \\
\hline Silt content: \% & 30.61 \\
\hline Clay content: \% & 1.10 \\
\hline Specific gravity $\left(G_{s}\right)$ & 2.59 \\
\hline \multicolumn{2}{|l|}{ Bulk density $\left(\gamma_{d}\right)$} \\
\hline Upper limit: $\mathrm{kN} / \mathrm{m}^{3}$ & 12.17 \\
\hline Lower limit: $\mathrm{kN} / \mathrm{m}^{3}$ & 8.03 \\
\hline \multicolumn{2}{|l|}{ Porosity (n) } \\
\hline Upper limit: \% & 69 \\
\hline Lower limit: \% & 53 \\
\hline \multicolumn{2}{|l|}{ Atterberg limit } \\
\hline Plastic limit: \% & - \\
\hline Liquid limit: \% & 40.6 \\
\hline Plasticity index: $\%$ & - \\
\hline $\begin{array}{l}\text { Unified Soil Classification } \\
\text { System (USCS)* }\end{array}$ & Sand with silt \\
\hline
\end{tabular}

Table 2. Details of the soil characteristics in Plexiglas cylinders.

\begin{tabular}{|c|c|c|c|}
\hline $\begin{array}{c}\text { ID } \\
\#\end{array}$ & $\begin{array}{c}\boldsymbol{\gamma}_{\mathbf{d}} \\
\mathbf{k N} / \mathbf{m}^{\mathbf{3}}\end{array}$ & $\mathbf{e}_{\mathbf{0}}$ & $\begin{array}{c}\mathbf{n}_{\mathbf{0}} \\
\mathbf{( \% )}\end{array}$ \\
\hline $\mathrm{C} 1$ & 12.30 & 1.27 & 56 \\
\hline $\mathrm{C} 2$ & 11.18 & 1.44 & 59 \\
\hline $\mathrm{C} 3$ & 10.93 & 1.50 & 60 \\
\hline $\mathrm{C} 4$ & 10.62 & 1.63 & 62 \\
\hline
\end{tabular}

The vegetation type used in this study belongs to the perennial graminae species, indigenous grasses that can adapt to different geo-environmental contexts and their climatic changes, also in dry conditions. This is essentially thanks to their capability to reach the deeper zones of the soil substrate where water is available (i.e. water springs, deep aquifers). Their fasciculate root system is able to reach up to 2 meters depth within the first vegetative year also in pyroclastic soils [17].

\subsection{Test set-up for vegetated soils}

Four plexiglas cylinders $200 \mathrm{~mm}$ high, called respectively $\mathrm{C} 1, \mathrm{C} 2, \mathrm{C} 3$ and $\mathrm{C} 4$, with inner and outer diameters respectively of $192 \mathrm{~mm}$ and $200 \mathrm{~mm}$, were filled with pyroclastic soil, by adopting the moist tamping method [18]. For an initial gravimetric water content $w$ of $10 \%$, four different initial bulk densities $\gamma_{d}$ $\left(12.3 \mathrm{kN} / \mathrm{m}^{3}, 11.18 \mathrm{kN} / \mathrm{m}^{3}, 10.93 \mathrm{kN} / \mathrm{m}^{3}\right.$ and 10.62 $\mathrm{kN} / \mathrm{m}^{3}$ ) were selected, corresponding respectively to $56 \%, 59 \% 60 \%$ and $62 \%$ of initial porosity $n_{0}$ (Table 2 ).

An amount of $3.5 \mathrm{~g}$ of graminae seeds was deposited on the soil surface of each cylinder. The samples were maintained in a greenhouse during the sprouting (3 weeks) and then placed outside the Geotechnical Laboratory of University of Salerno, under a rainout shelter for protection from direct rainfall. The seeds were watered every two days, at regular time intervals. A spray system was used to avoid that the direct flooding of water would lead to a volumetric collapse.

After 10 weeks of root growth, the height of soil in each cylinder was measured, so that the porosity variation due to vegetation growth was analysed. After 20 weeks the sampling process started.

\section{Experimental programme}

\subsection{Performed tests}

In order to investigate the effects of roots on the collapsible behaviour of pyroclastic unsaturated soils, standard oedometer tests [19] through incremental loading (IL) have been programmed and performed.

The oedometric apparatus consisted of a stainless steel rigid ring of $50 \mathrm{~mm}$ of diameter and $20 \mathrm{~mm}$ high, placed into a containing cell. The vertical load was applied through a frontal loading frame with a lever system where the load was charged. This load was then transferred through the lever to the upper surface of the sample where was uniformly distributed by a loading head. The axial deformation was measured by a LVDT with an accuracy of $0.01 \mathrm{~mm}$ opportunely connected to a computer for data acquisition.

The procedure adopted consisted in flooding the initially unsaturated sample, subjected to a consolidation pressure of $13 \mathrm{kPa}$, with distilled water.

For a fair comparison, oedometer tests have been performed preliminarily on bare reconstituted soil specimens, and thus on rooted specimens taken from the vegetated cylinders. The collapsibility coefficient [20] was calculated after each test as follows:

$$
\delta_{\mathrm{S}}(\%)=\Delta_{\mathrm{e}} /\left(e_{L}+1\right) 100
$$

where $e_{L}$ is the void ratio at the consolidation pressure of $13 \mathrm{kPa}$ and before the soil wetting, $\Delta_{\mathrm{e}}$ is the void ratio reduction due to saturation $\left(e_{L}-\mathrm{e}_{\text {flood }}\right)$, being $\mathrm{e}_{\text {flood }}$ the void ratio after flooding. In total 5 tests for bare reconstituted specimens and 12 tests for vegetated specimens at different initial soil porosity have been performed.

\subsection{Bare specimens preparation}

Reconstituted specimens have been formed in laboratory by adopting the same moist tamping technique used for filling the vegetated soil cylinders. The compaction procedure was conducted directly in the oedometer ring, in order to obtain the soil sample to test in oedometer apparatus. Five standard oedometer tests have been conducted on soil samples at five different $\gamma_{d}$, which correspond to initial porosities respectively of $52.5 \%$, $54.2 \%, 56.8 \%, 59.8 \%$ and $62.6 \%$ (Table 3). The initial saturation degree $\left(S_{r}\right)$ was about 0.2 for all the soil samples in order to investigate the effect of porosity on 
the volumetric collapse of soil.

Table 3. Details of oedometer tests on bare samples.

\begin{tabular}{|c|c|c|c|c|c|}
\hline $\begin{array}{c}\text { ID } \\
\# \\
\end{array}$ & $\begin{array}{c}\gamma_{d} \\
k N / m^{3}\end{array}$ & $\begin{array}{c}\mathbf{e}_{0} \\
- \\
\end{array}$ & $\begin{array}{c}\mathbf{e}_{\mathbf{L}} \\
-\end{array}$ & $\begin{array}{c}\mathbf{e}_{\text {flood }} \\
- \\
\end{array}$ & $\begin{array}{l}\delta_{\mathrm{s}} \\
\%\end{array}$ \\
\hline SO_B1 & 12.31 & 1.10 & 1.09 & 1.06 & 1.12 \\
\hline SO_B2 & 11.86 & 1.18 & 1.18 & 1.13 & 1.80 \\
\hline SO_B3 & 11.19 & 1.31 & 1.29 & 1.09 & 5.97 \\
\hline SO_B4 & 10.40 & 1.49 & 1.43 & 1.13 & 8.57 \\
\hline SO_B5 & 9.68 & 1.68 & 1.45 & 1.11 & 9.68 \\
\hline
\end{tabular}

Table 4. Details of root-soil specimens for oedometer tests.

\begin{tabular}{|c|c|c|c|c|c|}
\hline $\begin{array}{l}\text { ID } \\
\#\end{array}$ & $\begin{array}{c}\mathbf{e}_{0 \text { root }} \\
- \\
\end{array}$ & $\begin{array}{c}\mathbf{e}_{0 \text { root - }} \\
\text { average } \\
(\%)\end{array}$ & $\begin{array}{c}\mathbf{e}_{\mathrm{L}} \\
-\end{array}$ & $\begin{array}{c}\mathbf{e}_{\text {flood }} \\
-\end{array}$ & $\begin{array}{l}\delta s \\
\%\end{array}$ \\
\hline C1_1 & 1.11 & \multirow{3}{*}{1.04} & 1.06 & 1.05 & 0.14 \\
\hline $\mathrm{C} 1 \_2$ & 0.98 & & 0.96 & 0.96 & 0.03 \\
\hline $\mathrm{C} 1 \_3$ & 1.02 & & 1.00 & 0.99 & 0.08 \\
\hline $\mathrm{C} 2 \_1$ & 0.85 & \multirow{3}{*}{0.84} & 0.83 & 0.83 & 0.08 \\
\hline $\mathrm{C} 2 \_2$ & 0.86 & & 0.81 & 0.81 & 0.03 \\
\hline $\mathrm{C} 2 \_3$ & 0.80 & & 0.78 & 0.78 & 0.02 \\
\hline C3_1 & 1.17 & \multirow{3}{*}{1.16} & 1.12 & 1.12 & 0.40 \\
\hline C3_2 & 1.04 & & 1.02 & 1.01 & 0.24 \\
\hline C3_3 & 1.26 & & 1.21 & 1.20 & 0.34 \\
\hline C4_1 & 1.03 & \multirow{3}{*}{0.94} & 0.98 & 0.97 & 0.13 \\
\hline C4_2 & 0.90 & & 0.86 & 0.86 & 0.41 \\
\hline C4_3 & 0.88 & & 0.87 & 0.87 & 0.02 \\
\hline
\end{tabular}

\subsection{Vegetated specimens preparation}

\subsubsection{Sampling procedure}

After 20 weeks of growth, undisturbed root-soil samples were taken from each of the $200 \mathrm{~mm}$ high cylinders through a rigid sampler of $70 \mathrm{~mm}$ in diameter and 210 $\mathrm{mm}$ in length. First, the extra-leaves spreading out from the cylinder were cut in order to guarantee a good contact between the top of the sampler and the soil surface. After that, the sampler was introduced in rooted soil with a low penetration velocity to gently cut the lateral roots and to prevent that the soil would be dragged by lateral roots not yet broken. From each sampler the soil was extruded upwards and undisturbed root-soil samples with $50 \mathrm{~mm}$ diameter and $20 \mathrm{~mm}$ high were obtained (Fig. 1a). Once the specimen was obtained, the extra roots outing from the sample were cut (Fig. 1b) and both top surface and bottom surface have been carefully smoothed (Fig. 1c).

For each cylinder one sampling was conducted, from which 3 different root-soil specimens were taken respectively at $30 \mathrm{~mm}, 80 \mathrm{~mm}$ and $120 \mathrm{~mm}$ of depth. The ID of the specimens contains as first 2 letters the ID of the cylinder and, as last, the number of the specimen taken from that cylinder (from 1 to 3 from the shallowest to the deepest). Standard oedometer tests for vegetated samples taken by the four cylinders are summarized in Table 4 .

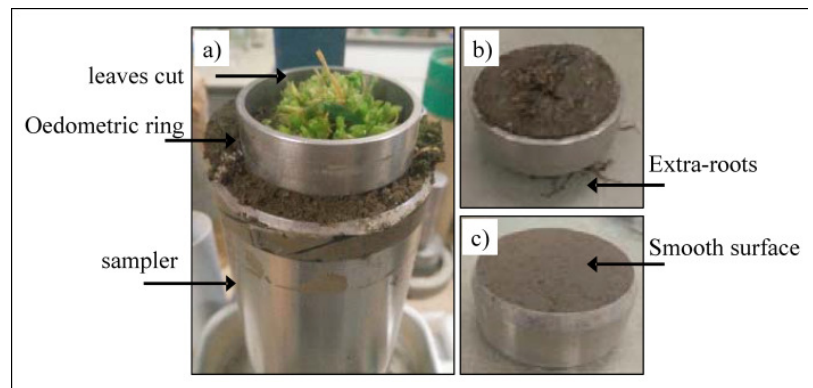

Fig. 1. Root-soil sampling procedure adopted: a) sampling process from the sampler with rigid oedometer ring, b) specimen with extra-roots and c) specimen with smoothed surfaces after cutting of extra-roots.

\subsubsection{Root-soil parameters}

After each test the root-soil parameters were determined. The void ratio of the vegetated specimens was calculated taking into account the fact that the roots, having a different specific gravity of solid grains, occupy some voids and thus may reduce the pore size. The void ratio was computed as follows:

$$
e_{0 \text { root }}=V_{\mathrm{v}} /\left(V_{s}+V_{r}\right)=\left(V_{\text {tot }}-V_{s^{-}}-V_{r}\right) /\left(V_{s}+V_{r}\right)
$$

where $V_{v}$ is the volume of the voids, obtained as the difference between the total volume $V_{t o t}$ and the volume occupied by the solid grains $V_{s}$ and roots $V_{r}$ calculated by considering a root density of $6.18 \mathrm{kN} / \mathrm{m}^{3}$, already measured in a related work [21]. The root volume was calculated as the ratio between the dry root biomass $(R M)$ and the root density $\left(\gamma_{r}\right)$. The root dry biomass $(R M)$ of each sample was measured according to the following procedure [22]: first, each sample was weighed and oven-dried at $60^{\circ} \mathrm{C}$ for $24 \mathrm{~h}$ and afterwards different sieves with decreasing diameter of the network were used to retain any roots contained in soil specimen. A tweezer was used to remove roots from soil retained at each sieve. Finally, $R M$ was weighed. To take into account the volume of roots occupying the pore spaces the Root Volume Density ( $R V D$ ) was calculated as the ratio between the total volume occupied by the roots, $V_{r}$, and the total volume of the soil sample $V_{\text {tot }}$ [23].

\section{Results}

\subsection{Bare soil}

The variation in void ratio of studied bare specimens after flooding in oedometer tests is observable in Figure 2 . The pairs of $e_{0}-e_{\text {flood }}$ for bare specimens subjected to wetting are shown for each specimen.

The bisector line separates the two main domains, the swelling potential domain, where $e_{\text {flood }}>e_{0}$, and the collapsible domain, where $e_{\text {flood }}<e_{0}$. The collapsible domain is limited by the literature values of void ratios 
found for these soils by previous studies, corresponding respectively at 1.13 (lower limit) and 2.23 (upper limit) [2]. The pairs of $e_{0}-e_{\text {flood }}$ for the bare reconstituted specimens after collapse show a tendency of reaching all a similar $e_{\text {flood }}$. The measured $e_{\text {flood }}$ as well as the collapsibility coefficient calculated for each specimen are reported in Table 3.

It is clearly observable that the initial void ratio influences the magnitude of collapse, in particular the higher the porosity (void ratio) the higher is the expected collapse due to wetting. Furthermore, all the specimens tend to decrease in volume until reaching a similar $e_{\text {flood, }}$, on average equal to 1.10 (dash-dotted line in Figure 2).

As matter of fact it is possible to argue that the void ratio 1.10 represents the lower value for which these pyroclastic soils can exhibit collapse due to wetting.

\subsection{Vegetated soil}

\subsubsection{Effect of roots growth on vegetated soil}

The effect of the roots growth on soil porosity variation for all cylinders is shown in Figure 3, where the void ratio $e$ computed at three different growth stages is reported: stage 1) corresponding to initial condition, stage 2) after 10 weeks of growing, and stage 3) corresponding to 20 weeks (when the specimens were taken). It can be observed that the initial porosity of rooted soil was progressively reduced compared to the initial condition in all cylinders and, in some cases, reached the lowermost value for which a collapsible response was still observed in bare specimens.

The decreasing trend observed in Figure 3 might be due to several factors such as: $i$ ) roots occupy pores and enhance soil aggregation, $\mathrm{ii}$ ) the dense and clustered root network produces exudates and this facilitates a reduction in soil porosity through links between soil particles, iii) stress-strain variation induced by wettingdrying cycles during the watering and evapotranspiration due to roots uptake.

\subsubsection{Root-soil parameters}

At the end of each oedometer test, the root dry biomass $(R M)$ was measured and consequently the Root Volume Density $(R V D)$ was calculated for each specimen (Tab. 5).

$R M$ range was in the same order of magnitude of previous findings in the same type of soil and the same type of vegetation [21]. Considering the initial void ratio of the vegetated cylinders $\left(e_{0}\right)$, the $R M$ increases proportionally with it. The same happens for $R V D$ and this might due to the higher availability of pores into the soil for roots to grow in.

Figure 4 shows the correlation between the initial void ratio of the cylinders $\left(e_{0}\right)$ and $R V D$ for rooted specimens taken at the three different sampling depths. It is clear that roots are able to grow better within a more porous initial soil structure and their volume decreases with the depth.



Fig. 2. Pairs of $e_{\text {flood }}-e_{0}$ and $\mathrm{e}_{\mathrm{L}}-e_{0}$; collapsible domain for bare specimens subjected to flood in oedometer tests. Upper and lower limits of void ratio of pyroclastic soils found in situ are also reported (vertical dashed lines).

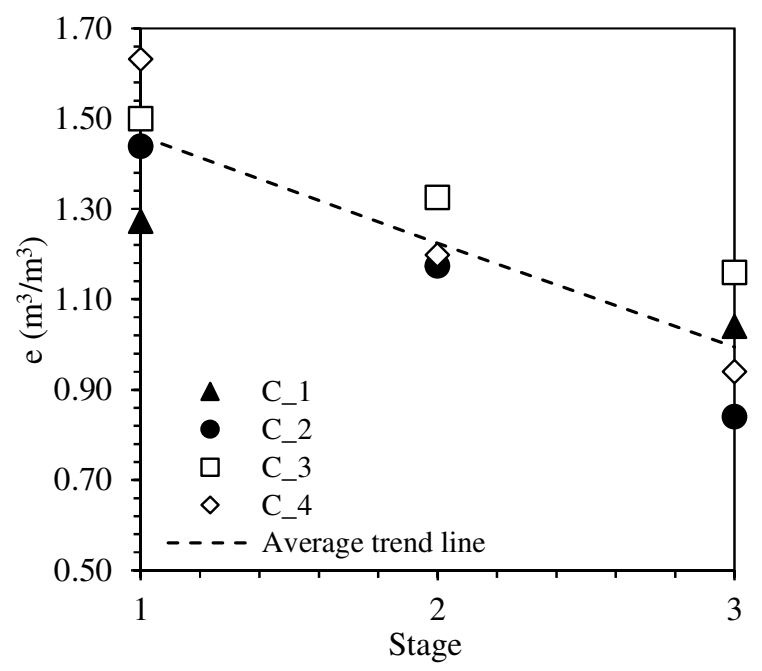

Fig. 3. Variation of the computed void ratio for rooted cylinders at three different stages and average trend line.

Table 5. Root parameters (RM and RVD) for each specimen subjected to collapse test.

\begin{tabular}{|c|c|c|c|}
\hline $\begin{array}{c}\text { ID } \\
\#\end{array}$ & $\begin{array}{c}\text { Depth } \\
(\mathrm{mm})\end{array}$ & $\begin{array}{c}\text { RM } \\
\text { (g) }\end{array}$ & $\begin{array}{c}\text { RVD } \\
(\%)\end{array}$ \\
\hline C1_1 & \multirow{4}{*}{30} & 0.18 & 0.73 \\
\hline C2_1 & & 0.22 & 0.90 \\
\hline C3_1 & & 0.30 & 1.21 \\
\hline C4_1 & & 0.32 & 1.29 \\
\hline C1_2 & \multirow{4}{*}{80} & 0.03 & 0.12 \\
\hline $\mathrm{C} 2 \_2$ & & 0.05 & 0.20 \\
\hline C3_2 & & 0.03 & 0.12 \\
\hline C4_2 & & 0.11 & 0.44 \\
\hline C1_3 & \multirow{4}{*}{120} & 0.01 & 0.08 \\
\hline C2_3 & & 0.06 & 0.25 \\
\hline C3_3 & & 0.02 & 0.08 \\
\hline C4_3 & & 0.04 & 0.16 \\
\hline
\end{tabular}






Fig. 4. Root Volume Density (RVD) for each specimen at the three different sampling depths vs initial void ratio $e_{0}$ of vegetated cylinders.

\subsubsection{Oedometer tests on vegetated soil}

Starting from the void ratio of root-soil samples already reduced due to root growth $\left(e_{0}\right.$ root $)$, the magnitude of collapse was investigated for $13 \mathrm{kPa}$ of vertical net stress applied. The variation of void ratio due to wetting and the coefficient of collapsibility $\left(\delta_{s}\right.$, eq. (1)) are reported in Table 4. The entity of collapse is highly reduced in root-soil samples mainly because of the initial void ratio $\left(e_{0}\right.$ root $)$. The initial porosity affects the entity of the collapse and in particular the higher is the initial porosity the higher is the expected volume deformation due to wetting, as already observed for bare specimens (Fig. 2). The highest void ratio among all root-soil samples was equal to 1.26 (C3_3), which is close to the lower void ratio at which a negligible collapse can occur for bare soil. Indeed, all the calculated coefficients of collapsibility were lower than $0.5 \%$, which can be considered as a negligible value for volume deformation.

\subsection{Comparison between collapse in bare and vegetated soil}

Figure 5 shows the calculated values of coefficient of collapsibility $\left(\delta_{s}\right.$, eq. (1)) of both bare and rooted specimens subjected to wetting at $13 \mathrm{kPa}$ of consolidation pressure into oedometer cell.

The trend of collapsibility for bare specimens increased with the initial void ratio. Both the magnitude of $\delta_{s}$ and the trend are confirmed by similar results obtained from a previous work on undisturbed pyroclastic soil at the same consolidation pressure [12]. The presence of roots reduced the volumetric deformation of the tested soil and the main cause was the reduction of void ratio during roots growth, thus is almost impossible to compare the bare soils and the vegetated soils. In all vegetated soils the initial void ratio are lower than those of reconstituted bare soil, except for three cases, where $e_{0}$ root are comparable to $e_{0} 1.12$ and

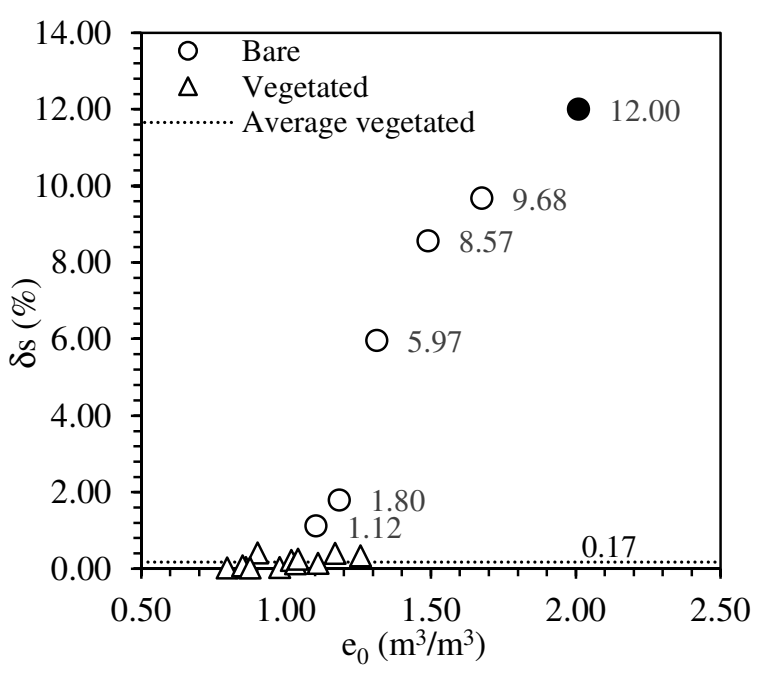

Fig. 5. Coefficient of collapsibility $\delta_{s}$ vs initial void ratio for bare $\left(e_{0}\right)$ and vegetated $\left(e_{0}\right.$ root $)$ specimens after wetting in oedometer tests. Coefficient of collapsibility of a similar oedometer test under the same initial vertical net stress on bare undisturbed specimen [12].

1.80 of bare specimens. For these latter it is possible to compare the magnitude of the calculated collapse, which resulted always lower than that of bare specimens. The average value of coefficient of collapsibility in rooted soils was $0.17 \%$, lower than the lowest value of collapsibility recorded for bare specimens (Fig. 5).

\section{Concluding remarks}

This work deals with the collapsibility of bare reconstituted specimens of pyroclastic soils and the role played by the presence of roots, belonging to perennial graminae species, on the behaviour of soil undergoing a wetting process. Since there is a lack of contribution in literature on the effect of roots on the collapsible behaviour of unsaturated soils, the results obtained in this study must be considered as first contribution to this challenging topic as it concerns pyroclastic soils. Wetting tests in oedometer cell were performed on partially saturated rooted-specimens under a consolidation pressure of $13 \mathrm{kPa}$, and the same tests were performed to reconstituted bare specimens for comparison. The obtained results highlight that the volume deformation due to wetting in bare soils has a strong porosity-dependency. In particular, the higher the initial soil porosity, the higher the magnitude of collapse was observed due to wetting. The collapse was found to be negligible when the void ratio is lower than 1.10 (corresponding to a porosity of $52.4 \%$ ).

Regarding the effect of roots on collapsibility of soils under wetting, on the basis of the experimental results obtained in this preliminary study, some hypotheses on rooted soil collapsible behaviour can currently be formulated. Particularly, it can be argued that roots growing in highly porous pyroclastic soils tend to aggregate the soil particles and thus reduce the porosity of the whole root-soil matrix. Numerous roots can better develop in highly porous structure than in denser soil, 
because they have more space available to move and grow. This means that despite the high porosity of pyroclastic soils, the roots can easily grow and enhance soil aggregation. As the void ratio of rooted-soil is reduced due to root growth, the volumetric deformation recorded during wetting under $13 \mathrm{kPa}$ of consolidation pressure was also reduced, according to the principle already observed in bare specimens: the higher the porosity the higher the collapse. The collapse magnitude of rooted-soil specimens with similar void ratios of bare specimens seems to be further reduced by roots. In conclusion, the roots tested in this study reduce the volumetric collapse of loose pyroclastic soils during saturation, thus reducing also the probability of static liquefaction during failure, as observed in a related work [21]. However, further studies are needed to understand the behaviour of rooted-soil during collapse at higher consolidation pressures.

\section{Acknowledgements}

The experimental tests reported in this work have been performed during the $\mathrm{PhD}$ research of Capobianco V. at the University of Salerno. The authors would like to acknowledge Prati Armati S.r.l. that provided the grass species used for the tests. The authors also wish to thank the Norwegian Geotechnical Institute for hosting part of the research period of the Post Doc Capobianco V. within WP3.2 Mitigation measures in the Research Council of Norway funded Klima 2050 project.

\section{References}

1. E. Damiano, L. Olivares, \& L. Picarelli. Eng. Geol. 137, 1-12 (2012).

2. E. Bilotta, L. Cascini, V. Foresta, \& G. Sorbino. Geotech. Geol. Eng. 23, 4, 365-402 (2005).

3. A. Ferrari, J. Eichenberger, \& L. Laloui. Géotechnique, 63, 16, 1433-1446 (2013).

4. L. Cascini, S. Cuomo, M. Pastor, \& G. Sorbino. J. Geotech. Geoenviron. Eng. 136, 1, 85-98. (2009).

5. D. Cazzuffi, A. Corneo, \& E. Crippa. Geotech. Geol. Eng. 24, 3, 429-447 (2006).

6. C. W. W. Ng, \& B. Menzies. Advanced unsaturated soil mechanics and engineering (USA: Taylor \& Francis, 2007).

7. C. W. W. Ng, \& A. K. Leung. J. Geotech. Geoenviron. Eng. 138, 58-65 (2012).

8. CA. Scanlan, \& C. Hinz. Proceedings of the 19th World Congress of Soil Science, 2: Brisbane, Australia; 41- 44 (2010).

9. P. Scholl, D. Leitner, G. Kammerer, W. Loiskandl, H. P. Kaul, \& G. Bodner. Plant Soil 381, 1-2, 193213 (2014).

10. O. Traoré, V. Groleau-Renaud, S. Plantureux, A. Tubeileh, \& V. Boeuf-Tremblay. Eur. J. Soil Sci. 51, 4, 575-581 (2000).

11. E. Bilotta, V. Foresta, \& G. Migliaro (2006). Unsaturated Soils, 849-860 (2006).
12. R. Lancellotta, C. Di Prisco, D. Costanzo, S. Foti, G. Sorbino, G. Buscarnera, R.M. Cosentini, V. Foresta. Caratterizzazione e modellazione geotecnica. In: Criteri di zonazione della suscettibilità e della pericolosità da frane innescate da eventi estremi (piogge e sisma)/Leonardo Cascini. (Composervice srl, Padova, pp. 266- 319. ISBN 9788890687334, 2012)

13. M. V. Nicotera. Effetti del grado di saturazione sul comportamento di una pozzolana del napoletano. (PhD Thesis, Università di Napoli Federico II, Italy, 1998).

14. E. Bilotta, V. Foresta, \& G. Migliaro. 1st European Conference on Unsaturated Soils, Durham, England, 1, 349-354 (2008).

15. M. Moscariello, S. Cuomo, \& S. Salager. Acta Geotech. 13, 1, 117-133 (2018).

16. C. Yuan, M. Moscariello, S. Cuomo, \& B. Chareyre, Granul. Matter 21, 3, 64-80 (2019).

17. V. Capobianco, L. Cascini, \& V. Foresta. Proceedings of China-Europe Conference on Geotechnical Engineering, 1260-1263. Springer, Cham (2018).

18. R.S. Ladd. ASCE J. Geotech. Eng. Div. 103, 6: 535-547 (1977).

19. ASTM D2435. Standard Test Methods for OneDimensional Consolidation Properties of Soils Using Incremental Loading (1996).

20. Y. M. Abelev. The essentials of designing and building on microporous soils. Stroitel'naya Promyshelmast, 10 (1984).

21. V. Foresta, V. Capobianco, \& L. Cascini. Can. Geotech. J. (accepted) (2019).

22. Y. M. Liang, D. L. Hazlett, \& W. K. Lauenroth. Oecologia 80, 2, 148-153 (1989).

23. H. Zhu, \& L. M. Zhang. Acta Geotech. 11, 5, 10471059 (2016). 